Int. J. Dev. Biol. 62: 57-62 (2018)

https://doi.org/10.1387/ijdb.180036op

\title{
Somite formation in the chicken embryo
}

\author{
OLIVIER POUROUIÉ*,1,2,3 \\ ${ }^{1}$ Department of Genetics, Harvard Medical School, ${ }^{2}$ Department of Pathology, Brigham and Women's Hospital and \\ ${ }^{3}$ Harvard Stem Cell Institute, Boston, MA, USA
}

\begin{abstract}
Somites are epithelial blocks of paraxial mesoderm that define the vertebrate embryonic segments. They are responsible for imposing the metameric pattern observed in many tissues of the adult such as the vertebrae, and they give rise to most of the axial skeleton and skeletal muscles of the trunk. Due to its easy accessibility in the egg, the chicken embryo has provided an ideal model to study somite development. Somites were first described in the chicken embryo by Malpighi in the $17^{\text {th }}$ century, soon after the invention of the microscope. Most of the major concepts relating to somite segmentation and differentiation result from studies performed in the chicken embryo (Brand-Saberi and Christ, 2000). In this review, we will discuss how studies on somites in avian embryos have contributed to our understanding of key developmental processes such as segmentation, control of bilateral symmetry or axis regionalization.
\end{abstract}

KEY WORDS: presomitic mesoderm, muscle, segmentation clock

\section{Somite segmentation}

Somites form bilaterally on both sides of the neural tube and notochord from the presomitic mesoderm (PSM) which is produced by ingression of the epiblast during gastrulation in the primitive streak and tail bud. Together with the head mesoderm anteriorly, somites and PSM form the paraxial mesoderm. Somite formation proceeds until 52-55 somites are formed in the chicken embryo. This number is similar to humans but different from zebrafish which form 30 somites or from mice which form 65 . Soon after their formation, somites subdivide into a ventral mesenchymal compartment, the sclerotome, fated to give rise to the axial skeleton and a dorsal epithelial compartment, the dermomyotome which will form the skeletal muscles of the body and the dermis of the back. Somitic derivatives subsequently acquire a regional identity under the influence of Hox genes, thus defining the characteristic anatomical domains of the body, such as the cervical, thoracic or lumbo-sacral regions. While the overall sequence of anatomical domains is conserved in evolution, the number of vertebrae contributing to these different regions is different from that seen in mammals and for example, chicken and quail embryos have 14 cervical vertebrae while most mammals including mice have only 7 (Burke et al., 1995, Christ and Ordahl, 1995).

The study of somite patterning and differentiation has made tremendous progress since the 1960s. The development of the quail-chick chimera technique has allowed a precise mapping of the fate of the somitic derivatives, leading to the characterization of all the lineages derived from the somites (Le Douarin, 1969). The description of highly sensitive protocols for in situ hybridization has made possible very detailed characterization of gene expression during avian somitogenesis (Henrique et al., 1995, Palmeirim et al., 1997). Studies of somite patterning and differentiation have also been significantly enhanced by the introduction of the in ovo electroporation technique (Yasugi and Nakamura, 2000). This technique permits to overexpress plasmids driving expression of a construct of interest together with a fluorescent protein in embryonic tissues. Specific methods have been developed to target either the early paraxial mesoderm or the various somitic compartments (Dubrulle et al., 2001, Gros et al., 2004, limura and Pourquie, 2008). Using this technique, detailed molecular dissections of the various signaling pathways implicated in somite patterning have been performed. Compared to mouse embryos which form a cup shaped embryo during early stages of development, the chicken embryo is flat and thus much easier to observe during early somitogenesis stages. Moreover, avian embryos are much easier to culture than mammalian embryos as for instance, they do not require specific control of $\mathrm{CO}_{2}$ or $\mathrm{O}_{2}$ concentration (Chapman et al., 2001, New, 1955). Combined to the recent development of transgenic chicken and quail reporter lines which express fluorescent proteins, this has enabled the development of sophisticated imaging protocols (McGrew et al., 2008, Sato and Lansford, 2013).

Abbreviations used in this paper: AP, antero-posterior; PSM, presomitic mesoderm.

\footnotetext{
*Address correspondence to: Olivier Pourquié. 60 Fenwood Road, 02115 Boston, MA, USA. e-mail: pourquie@genetics.med.harvard.edu - (iD) http://orcid.org/0000-0001-5189-1227
} 


\section{Somite segmentation}

Studies in the chicken embryo have contributed to major advances in the field of vertebrate segmentation. In the chicken embryo, pairs of somites are periodically formed at the tip of the PSM with a defined rhythm of 90 minutes per pair. This rhythm is characteristic of the species and while it is similar in quail, somite formation in mouse exhibits a 2 hour-period and in zebrafish a 30 minute-period. Microsurgical inversions of the PSM coupled to time-lapse microscopy demonstrated that the PSM kept its endogenous segmentation schedule, leading to an inverted series of segments (Christ et al., 1974b, Menkes and Sandor, 1969, Palmeirim et al., 1998). This argued that segmentation exhibits a high degree of autonomy at the tissue level. The observation of regular groups of more densely packed cells along the PSM using scanning electron microscopy led to propose the existence of prepatterned segments (somitomeres) along the PSM (Jacobson, 1988, Packard and Meier, 1983). However, such a prepattern could not be identified at the molecular level except in the anterior PSM, therefore arguing against the existence of the somitomeres.

The existence of a somitomeric prepattern was further challenged by the identification of the periodic expression of the transcription factor $C-H A I R Y 1$ in the chicken embryo PSM (Palmeirim et al., 1997). This provided the first evidence for an oscillator associated to segmentation which was called "Segmentation clock" (Palmeirim et al., 1997). While several different hypotheses aiming at explaining the sequential and rhythmic production of somites had been proposed (Bellairs, 1985, Keynes and Stern, 1988, Meinhardt, 1986), identification of the segmentation clock supported the "clock and wavefront" model (Cooke and Zeeman, 1976) which postulated the existence of an oscillator controlling the rhythmicity of segmentation. This work was quickly followed by the identification of the Notch target Lunatic Fringe (LFNG) as another cyclic gene oscillating in phase with $C-H A I R Y 1$ in the chicken embryo PSM (Aulehla and Johnson, 1999, McGrew et al., 1998). Following this pioneering work, cyclic genes showing periodic expression patterns were identified in other vertebrates such as mouse, fish as well as in invertebrates such as Tribolium, suggesting that the segmentation clock might represent a component of an ancestral segmentation system (Forsberg et al., 1998, Holley et al., 2000, Sarrazin et al., 2012). Cyclic genes downstream of other pathways such as SNAIL2 and PAPC or AXIN2 which are downstream of FGF and Wnt signaling respectively were also identified in chicken embryos (Chal et al., 2017, Dale et al., 2006, Krol et al., 2011).

First insights into the regulatory network underlying the segmentation clock oscillations indicated that periodic Notch signaling is involved in the regulation of hairy-like genes ( $C-H A I R Y 1$ and 2 in chicken and Hes1 in mouse) a process involving Lunatic Fringe driving periodic Notch inhibition (Dale et al., 2003, Morimoto et al., 2005). Comparison of the whole set of cyclic genes identified using a microarray strategy between chicken, mouse and zebrafish demonstrated that the same signaling pathways but not the same genes are periodically regulated in these different species (Krol et al., 2011). The onset of the segmentation clock has been first studied in the chicken embryo where the first two oscillations are observed during production of the head and prechordal mesoderm while the third oscillation marks the production of the first somite (Jouve et al., 2002).
In the clock and wavefront model, the wavefront corresponds to a maturation wave that moves posteriorly as the embryo elongates and allows the periodic conversion of the response to the oscillator into a spatial series of segments (Cooke and Zeeman, 1976, Hubaud and Pourquie, 2014). Microsurgical inversions of somite-size fragments along the PSM identified a level, termed determination front, at which segmental identity becomes fixed (Dubrulle et al., 2001). This level is slightly posterior to the level where the first stripes of CMESO1/Mesp2 gene expression are observed. Posterior to the determination front, inversions lead to normal somitogenesis whereas anteriorly, inverted somites are formed. Further studies in the chicken embryo identified an FGF signaling gradient peaking in the tail bud which plays an important role in segmentation. The FGF gradient was proposed to define the position of the determination front as a threshold level at which cells become competent to respond to the periodic signal of the segmentation clock (Delfini et al., 2005, Dubrulle et al., 2001). Thus, the size of the future segment would be defined by the distance traveled by this threshold during one oscillation of the clock. These predictions are supported by experiments showing that the size of the segment can be predictably changed by interfering with FGF signaling. For instance, grafting FGF-producing beads, which is expected to delay the wavefront progression, leads to the formation of smaller somites while treatment with FGF inhibitors such as SU5402 results in the production of larger somites consistent with an acceleration of wavefront regression (Dubrulle et al., 2001). A parallel gradient of Wnt signaling is established in mouse and chicken embryos and does also play a role in specifying the determination front position (Aulehla et al., 2003, Aulehla et al., 2008). Graft of Wnt3a-producing beads leads to the formation of smaller somites, suggesting that Wnt is also involved in positioning the determination front. Furthermore, overexpression of constructs activating FGF signaling in the PSM by electroporation maintains expression of posterior PSM markers such as Brachyury and prevents expression of the Mesp2-related genes eventually blocking segmentation (Delfini et al., 2005, Dubrulle et al., 2001). Remarkably, this FGF gradient is established via an unusual mechanism wherein transcription of the Fgf8 ligand mRNA stops as the descendents of the tail bud PSM precursors enter the posterior PSM (Dubrulle and Pourquie, 2004). Due to the elongation movements involved in PSM production, PSM cells become progressively located more anteriorly in the PSM as the amount of FGF8 they contain gradually decays. This mechanism results in the establishment of a dynamic FGF signaling gradient that regresses together with the progressive elongation of the embryo.

One of the striking aspects of amniote segmentation is the tight coordination between somite production on the right and the left side. Retinoic acid (RA) plays an important role in the control of the bilateral symmetry of somitogenesis as inhibition of the RA biosynthetic enzyme, Raldh2 either by mutation in mouse or fish or by treating chicken embryos with a chemical inhibitor (Disulfiram), results in a lateralized desynchronization of somite formation (Kawakami et al., 2005, Vermot et al., 2005, Vermot and Pourquie, 2005). Situs reversal using grafts of Sonic Hedgehog beads in the chicken embryo leads to a concomitant reversal of the somitogenesis defects (Vermot and Pourquie, 2005). Thus RA acts to buffer somitogenesis against desynchronizing influences of the left-right machinery. Strikingly, the somitogenesis defects 
are observed in opposite sides in mouse and chicken embryos, exhibiting a right delay of somite formation in mouse while in chicken it is observed on the left side (Vermot et al., 2005, Vermot and Pourquie, 2005). This behavior is paralleled by the asymmetric expression of the nuclear receptor NR2F2 (Coup-Tf2) which shows a stronger expression in the right mouse PSM while in chicken it is on the left (Vilhais-Neto et al., 2010). Nr2f2 interacts with RA signaling in the PSM potentially explaining the reversed defect of somitogenesis in the two species. Since in both species, Nodal is located on the left side, this also argues that RA is not acting by buffering Nodal action. RA signaling acting via its co-activator Rere/Atrophin2 antagonizes FGF signaling and is required to maintain the bilateral symmetry of the FGF gradient (Vilhais-Neto et al., 2010). Interestingly, Fgf8 which is a key element of the posterior gradient controlling segmentation was shown to act as determinant of the left identity in mouse while in the chicken it is a right determinant (Boettger et al., 1999, Meyers and Martin, 1999). Together, these data argue that RA signaling acts to buffer the desynchronizing action of the left-right determinant FGF signaling to maintain the bilateral symmetry of somite formation.

\section{Rostro-caudal patterning of somites and resegmenta- tion}

In the $19^{\text {th }}$ century, based on histological observations of chicken embryo development, Remak concluded that vertebrae do not derive from a single pair of somites but rather from the fusion of two consecutive pair of half-somites, a process he called resegmentation (reviewed in Brand-Saberi and Christ, 2000). This implies that somites can be subdivided into an anterior and a posterior compartment. The first evidence for segmentation in the PSM corresponds to bilateral stripes of expression of the transcription factors of the Mesp2 family which encompass a domain of the size of a future segment (Buchberger et al., 2002, Buchberger et al., 1998). Immediately after their formation, these stripes resolve into a smaller domain which marks the future anterior domain of the forming somite, thus defining the rostrocaudal identity of the future somitic compartments. Several other genes, including C-HAIRY1 and UNCX4.1, or LFNG and TBX18 are expressed either in the anterior or the posterior compartment of the forming somite respectively (McGrew et al., 1998, Palmeirim et al., 1997, Schragle et al., 2004, Tanaka and Tickle, 2004). This antero-posterior subdivision of the somites is materialized in the sclerotome by the fissure of Von Ebner which separates the two compartments (Von Ebner, 1888). While both sclerotome halves give rise to the vertebral body, the caudal half forms the vertebral pedicle and the rostral half produces the intervertebral disk (Goldstein and Kalcheim, 1992). Axons of the motoneurons and neural crest cells only migrate in the anterior compartment of the sclerotome (Bronner-Fraser, 1986, Keynes and Stern, 1984, Rickmann et al., 1985). Inversion of portions of the anterior PSM along the AP axis results in an inversion of the AP polarity of the forming somites (Keynes and Stern, 1984, Palmeirim et al., 1998). Strikingly, axons of the motor neurons still migrate through the anterior compartment of the inverted tissue (Keynes and Stern, 1984). Such microsurgical manipulations demonstrated that only the anterior portion of the sclerotome is permissive for the migration of neural crest cells or motoneurons axons. The posterior sclerotome is refractory to their migration. Replacement of host half-somites with either rostral or caudal donor half-somites show that only half somites with the same identity do mix (Stern and Keynes, 1987). Therefore, the antero-posterior compartmentalization of the somites is determined prior to somite formation in the anterior PSM and it plays a key role in peripheral nervous system segmentation (Krull, 2001).

The anterior PSM progressively becomes epithelial and somite formation mostly consists in creating a fissure separating the forming somite from the PSM (Nakaya et al., 2004). Thus, formation of a posterior boundary is a key event in somite formation as it leads to the separation of an epithelial sphere surrounding a mesenchymal core (the somitocoele) from the PSM. The position of the future posterior boundary is marked by the interface between the Mesp2 (MESO1)-positive (Notch activated) and Mesp2-negative territories (Notch inactive) which arises as a new stripe of Mesp2 expression forms as a result of the segmentation clock oscillations (Oginuma et al., 2008, Watanabe et al., 2009). MESO1 triggers expression of EPHA4 which in turn regulates Cdc42 leading to fissure formation (Nakaya et al., 2004, Sato et al., 2002, Watanabe et al., 2009). This process also involves the paraxial protocadherin PAPC acting downstream of MESO1 to control endocytosis of $\mathrm{CDH} 2$ and promote fissure formation (Chal et al., 2017). Grafting a fragment of the posterior primitive streak with Noggin beads in the area opaca of a chicken host results in the production of rosettes of paraxial mesoderm resembling somites but lacking the characteristic alignment of somites and their rostro-caudal identity (Dias et al., 2014). Thus while this suggests that somitic boundaries tend to spontaneously form, in the embryo, the timing of their formation appears to be tightly regulated by the segmentation clock.

\section{Mapping the fate of somitic cells}

By microsurgery, newly formed somites can be easily removed from a chicken host embryo and replaced by a donor somite of a quail embryo from the same level (Ordahl and Christ, 1997). Using this technique, vertebrae, ribs, tendons, meninges of the spinal cord, dorsal dermis, some blood vessels and all skeletal muscles were shown to derive from somites (Brent et al., 2003, Chevallier, 1975, Christ et al., 2007, Olivera-Martinez et al., 2000). The chicken embryo produces 55 somites, which for the 7 most anterior ones contribute to the occipital bones, while the rest forms the vertebral column (Christ and Ordahl, 1995, Couly et al., 1993a, Huang et al., 1997, Huang et al., 2000a). A somitic contribution to the scapula was also identified (Chevallier, 1975, Huang et al., 2000b, Shearman et al., 2011). Detailed mappings of the contribution of individual somites to specific muscles and dermis regions along the AP axis have been performed, demonstrating significant migration of these derivatives along the AP axis (Beresford, 1983, Beresford et al., 1978, Chevallier et al., 1977, Christ et al., 1974a, Christ et al., 1976, Christ et al., 1977, Christ et al., 1983, Couly et al., 1993b, Jacob et al., 1979, Lance-Jones, 1988, Noden, 1983). Importantly, such studies showed that limb muscle precursors originate from the somite and migrate from the lateral dermomyotome into the lateral plate (Chevallier et al., 1977, Christ et al., 1974a). Using Dil labeling and quail-chick chimeras, somites were shown to be subdivided into a medial compartment that gives rise to sclerotome, paraxial muscles and dermis, while the lateral compartment produces the muscles of the limbs and 
girdles (Ordahl and Le Douarin, 1992, Selleck and Stern, 1991). Remarkably, microsurgical separation of the medial and lateral PSM shows that only the medial cells can segment and maintain cyclic gene oscillations, suggesting that communication between the medial and lateral compartments is required for somite segmentation (Freitas et al., 2001).

\section{Somites are patterned by signals from surrounding tissues}

Graft of a quail somite in an inverted dorso-ventral orientation in a chicken host leads to normal differentiation of the somitic derivatives (Aoyama and Asamoto, 1988). This indicated that somitic cells are equally plastic at the time of their formation, arguing for a role of the surrounding tissues in the specification of the various somitic derivatives. Ectopic grafts or ablations of the surrounding structures such as the notochord, the neural tube, the ectoderm or the lateral plate have established their role in the patterning of the different somitic regions. For instance, such manipulations have demonstrated the role of the notochord and floor plate in sclerotome induction (Pourquie et al., 1993, Strudel, 1955), while the ectoderm and neural tube promote dermomyotome formation (Mauger, 1972, Stern and Hauschka, 1995). These experiments have led to the identification of the molecular signals implicated in the induction of the various lineages. Such signals include Sonic Hedgehog produced by the Notochord and floor plate for sclerotome induction (Fan and Tessier-Lavigne, 1994, Johnson et al., 1994), Wnts produced by the ectoderm and neural tube for the dermomyotome (Hirsinger et al., 1997, Marcelle et al., 1997) and BMP4 produced by the lateral plate for the lateral somite fate (Pourquie et al., 1996). The electroporation technique has also been very effectively used to perform high resolution imaging studies which have clarified the early stages of myogenesis from the myotome (Gros et al., 2004). Early studies based on quail-chick chimeras argued that the medial lip of the dermomyotome was the major contributor to the myotome (Kaehn et al., 1988, Ordahl et al., 2001). High resolution live imaging following the fate of the derivative of the different dermomyotome compartments labeled with fluorescent proteins by electroporation demonstrated that all four lips of the dermomyotome contribute to the myotome in a specific order(Gros et al., 2004).

\section{Regional patterning of somitic derivatives}

Soon after their formation, somitic derivatives become patterned according to their anatomical region. Substitution of the PSM from the future thoracic region by PSM of the future cervical region results in the formation of ribs in the neck region of transplanted animals (Kieny et al., 1972). Such experiments demonstrated that regional identity of somitic derivatives is established early in the PSM. This regional identity of paraxial mesoderm derivatives is largely imparted by the Hox genes which code for a family of 39 transcription factors arranged in collinear order in four clusters in the chicken embryo chromosomes (Wellik, 2007). Hox genes are expressed in the paraxial mesoderm in a temporal sequence which reflects the position of the genes on the chromosomes (temporal collinearity)(Dolle et al., 1989, limura and Pourquie, 2007). This sequential expression of the genes ultimately results in the formation of collinear domains along the body axis, with the genes located more 3' (anterior genes) in the cluster showing an expression boundary located more anteriorly than the 5 ' genes (posterior genes). Electroporation of Hox gene constructs in the chicken embryo epiblast shows that genes are able to control the timing of ingression of cells fated to form the PSM (limura and Pourquie, 2006). Strikingly, the more posterior the gene is expressed, the more it delays cell ingression suggesting that the collinear activation of genes in the epiblast controls the ingression schedule of paraxial mesoderm derivatives. Combined to the progressive elongation of the body axis, these properties are expected to result in the collinear distribution of Hox gene expression domains in the paraxial mesoderm potentially explaining how the temporal collinearity is translated into spatial collinearity. How Hox genes subsequently direct the regional morphology of vertebrae and other somitic derivatives remains poorly understood.

The more posterior Hox genes were also shown to control posterior elongation of the chicken embryo via a collinear repression of Wnt signaling which controls paraxial mesoderm production in the tail bud (Denans et al., 2015). By slowing down axis elongation while somitogenesis progression remains constant, posterior Hox gene expression is expected to lead to a shrinking of the PSM ultimately leading to termination of axis extension. This mechanism was proposed to play a role in the control of segment number in the chicken embryo.

\section{References}

AOYAMA, H. and ASAMOTO, K. (1988). Determination of somite cells: independence of cell differentiation and morphogenesis. Development 104: 15-28.

AULEHLA, A. and JOHNSON, R.L. (1999). Dynamic expression of lunatic fringe suggests a link between notch signaling and an autonomous cellular oscillator driving somite segmentation. Dev Biol 207: 49-61.

AULEHLA, A., WEHRLE, C., BRAND-SABERI, B., KEMLER, R., GOSSLER, A., KANZLER, B. and HERRMANN, B.G. (2003). Wnt3a plays a major role in the segmentation clock controlling somitogenesis. Dev Cell 4: 395-406.

AULEHLA, A., WIEGRAEBE, W., BAUBET, V., WAHL, M.B., DENG, C., TAKETO, M., LEWANDOSKI, M. and POURQUIE, O. (2008). A beta-catenin gradient links the clock and wavefront systems in mouse embryo segmentation. Nat Cell Biol 10: 186-193.

BELLAIRS, R. (1985). A new theory about somite formation in the chick. Prog.Clin. Biol.Res. 171: 25-44

BERESFORD, B. (1983). Brachial muscles in the chick embryo: the fate of individual somites. J.Embryol.Exp.Morphol. 77: 99-116.

BERESFORD, B., LE LIEVRE, C. and RATHBONE, M.P. (1978). Chimaera studies of the origin and formation of the pectoral musculature of the avian embryo. J.Exp. Zool. 205: 321-326.

BOETTGER, T., WITTLER, L. and KESSEL, M. (1999). FGF8 functions in the specification of the right body side of the chick. Curr Biol 9: 277-280.

BRAND-SABERI, B. and CHRIST, B. (2000). Evolution and development of distinct cell lineages derived from somites. Curr Top Dev Biol 48: 1-42.

BRENT, A.E., SCHWEITZER, R. and TABIN, C.J. (2003). A somitic compartment of tendon progenitors. Cell 113: 235-248.

BRONNER-FRASER, M. (1986). Analysis of the early stages of trunk neural crest migration in avian embryos using monoclonal antibody HNK-1. Dev Biol. 115: 44-55.

BUCHBERGER, A., BONNEICK, S., KLEIN, C. and ARNOLD, H.H. (2002). Dynamic expression of chicken cMeso2 in segmental plate and somites. Dev Dyn 223: 108-118.

BUCHBERGER, A., SEIDL, K., KLEIN, C., EBERHARDT, H. and ARNOLD, H.H. (1998). cMeso-1, a novel bHLH transcription factor, is involved in somite formation in chicken embryos. Dev Biol 199: 201-215.

BURKE, A.C., NELSON, C.E., MORGAN, B.A. and TABIN, C. (1995). Hox genes and the evolution of vertebrate axial morphology. Development 121: 333-346. 
CHAL, J., GUILLOT, C. and POURQUIE, O. (2017). PAPC couples the segmentation clock to somite morphogenesis by regulating $\mathrm{N}$-cadherin-dependent adhesion. Development 144: 664-676.

CHAPMAN, S.C., COLLIGNON, J., SCHOENWOLF, G.C. and LUMSDEN, A. (2001). Improved method for chick whole-embryo culture using a filter paper carrier. Dev Dyn 220: 284-289.

CHEVALLIER, A. (1975). [Role of the somitic mesoderm in the development of the rib cage of bird embryos. I. Origin of the sternal component and conditions for the development of the ribs (author's transl)]. J Embryol Exp Morphol 33: 291-311.

CHEVALLIER, A., KIENY, M. and MAUGER, A. (1977). Limb-somite relationship: origin of the limb musculature. J.Embryol.Exp.Morphol. 41: 245-258.

CHRIST, B., HUANG, R. and SCAAL, M. (2007). Amniote somite derivatives. Dev Dyn. 236: 2382-2396.

CHRIST, B., JACOB, H.J. and JACOB, M. (1974a). Origin of wing musculature. Experimental studies on quail and chick embryos. Experientia. 30: 1446-1449.

CHRIST, B., JACOB, H.J. and JACOB, M. (1974b). Somitogenesis in the chick embryo. Determination of the segmentation direction. Verh.Anat.Ges. 68: 573-579.

CHRIST, B., JACOB, H.J. and JACOB, M. (1976). Origin of greater and smaller pectoral muscles. Experiments with quail and chick embryos. Verh.Anat.Ges. 70: 1007-1011.

CHRIST, B., JACOB, H.J. and JACOB, M. (1977). Experimental analysis of the origin of the wing musculature in avian embryos. Anat.Embryol.(Berl). 150: 171-186.

CHRIST, B., JACOB, M. and JACOB, H.J. (1983). On the origin and development of the ventrolateral abdominal muscles in the avian embryo. An experimental and ultrastructural study. Anat.Embryol.(Berl). 166: 87-101.

CHRIST, B. and ORDAHL, C.P. (1995). Early stages of chick somite development. Anat.Embryol.(Berl). 191: 381-396.

COOKE, J. and ZEEMAN, E.C. (1976). A clock and wavefront model for control of the number of repeated structures during animal morphogenesis. $J$ Theor Biol 58: $455-476$.

COULY, G., COLTEY, P. and LE DOUARIN, N.M. (1993a). The triple origin of skull in higher vertebrates: a study in quail-chick chimeras. Dev.Suppl. 117: 409-429.

COULY, G.F., COLTEY, P.M. and LE DOUARIN, N.M. (1993b). The triple origin of skull in higher vertebrates: a study in quail-chick chimeras. Development 117:409-429.

DALE, J.K., MALAPERT, P., CHAL, J., VILHAIS-NETO, G., MAROTO, M., JOHNSON, T., JAYASINGHE, S., TRAINOR, P., HERRMANN, B. and POURQUIE, O. (2006). Oscillations of the snail genes in the presomitic mesoderm coordinate segmental patterning and morphogenesis in vertebrate somitogenesis. Dev Cell10:355-366.

DALE, J.K., MAROTO, M., DEQUEANT, M.L., MALAPERT, P., MCGREW, M. and POURQUIE, O. (2003). Periodic Notch inhibition by Lunatic Fringe underlies the chick segmentation clock. Nature 421: 275-278.

DELFINI, M.C., DUBRULLE, J., MALAPERT, P., CHAL, J. and POURQUIE, O. (2005) Control of the segmentation process by graded MAPK/ERK activation in the chick embryo. Proc Natl Acad Sci USA 102: 11343-11348.

DENANS, N., IIMURA, T. and POURQUIE, O. (2015). Hox genes control vertebrate body elongation by collinear Wnt repression. Elife 4.

DIAS, A.S., DE ALMEIDA, I., BELMONTE, J.M., GLAZIER, J.A. and STERN, C.D. (2014). Somites without a clock. Science 343: 791-795.

DOLLE, P., IZPISUA-BELMONTE, J.C., FALKENSTEIN, H., RENUCCI, A. and DUBOULE, D. (1989). Coordinate expression of the murine Hox-5 complex homoeobox-containing genes during limb pattern formation. Nature 342: 767-772.

DUBRULLE, J., MCGREW, M.J. and POURQUIE, O. (2001). FGF signaling controls somite boundary position and regulates segmentation clock control of spatiotemporal Hox gene activation. Cell 106: 219-232.

DUBRULLE, J. and POURQUIE, O. (2004). fgf8 mRNA decay establishes a gradient that couples axial elongation to patterning in the vertebrate embryo. Nature 427: 419-422.

FAN, C.M. and TESSIER-LAVIGNE, M. (1994). Patterning of mammalian somites by surface ectoderm and notochord: evidence for sclerotome induction by a hedgehog homolog. Cell 79: 1175-1186.

FORSBERG, H., CROZET, F. and BROWN, N.A. (1998). Waves of mouse Lunatic fringe expression, in four-hour cycles at two-hour intervals, precede somite boundary formation. Curr.Biol. 8: 1027-1030.

FREITAS, C., RODRIGUES, S., CHARRIER, J.B., TEILLET, M.A. and PALMEIRIM, I. (2001). Evidence for medial/lateral specification and positional information within the presomitic mesoderm. Development 128: 5139-5147

GOLDSTEIN, R.S. and KALCHEIM, C. (1992). Determination of epithelial half-somites in skeletal morphogenesis. Development. 116: 441-445.

GROS, J., SCAAL, M. and MARCELLE, C. (2004). Atwo-step mechanism for myotome formation in chick. Dev Cell 6: 875-882.

HENRIQUE, D., ADAM, J., MYAT, A., CHITNIS, A., LEWIS, J. and ISH-HOROWICZ, D. (1995). Expression of a Delta homologue in prospective neurons in the chick. Nature 375: 787-790.

HIRSINGER, E., DUPREZ, D., JOUVE, C., MALAPERT, P., COOKE, J. and POURQUIE, O. (1997). Noggin acts downstream of Wnt and Sonic Hedgehog to antagonize BMP4 in avian somite patterning. Development 124: 4605-4614.

HOLLEY, S.A., GEISLER, R. and NUSSLEIN-VOLHARD, C. (2000). Control of her1 expression during zebrafish somitogenesis by a delta-dependent oscillator and an independent wave-front activity. Genes Dev 14: 1678-1690.

HUANG, R., ZHI, Q., ORDAHL, C.P. and CHRIST, B. (1997). The fate of the first avian somite. Anat.Embryol.(Berl). 195: 435-449.

HUANG, R., ZHI, Q., PATEL, K., WILTING, J. and CHRIST, B. (2000a). Contribution of single somites to the skeleton and muscles of the occipital and cervical regions in avian embryos. Anat Embryol (Berl) 202: 375-383.

HUANG, R., ZHI, Q., PATEL, K., WILTING, J. and CHRIST, B. (2000b). Dual origin and segmental organisation of the avian scapula. Development 127: 3789-3794.

HUBAUD, A. and POURQUIE, O. (2014). Signalling dynamics in vertebrate segmentation. Nat Rev Mol Cell Biol 15: 709-721.

IIMURA, T. and POURQUIE, O. (2006). Collinear activation of Hoxb genes during gastrulation is linked to mesoderm cell ingression. Nature 442: 568-571.

IIMURA, T. and POURQUIE, O. (2007). Hox genes in time and space during vertebrate body formation. Dev Growth Differ 49: 265-275.

IIMURA, T. and POURQUIE, O. (2008). Chapter 13 manipulation and electroporation of the avian segmental plate and somites in vitro. Methods Cell Biol 87: 257-270.

JACOB, M., CHRIST, B. and JACOB, H.J. (1979). The migration of myogenic cells from the somites into the leg region of avian embryos. An ultrastructural study. Anat.Embryol.(Berl). 157: 291-309.

JACOBSON, A.G. (1988). Somitomeres: mesodermal segments of vertebrate embryos Development. 104 Suppl: 209-220.

JOHNSON, R.L., LAUFER, E., RIDDLE, R.D. andTABIN, C. (1994). Ectopic expression of Sonic hedgehog alters dorsal-ventral patterning of somites. Cell79: 1165-1173.

JOUVE, C., IIMURA, T. and POURQUIE, O. (2002). Onset of the segmentation clock in the chick embryo: evidence for oscillations in the somite precursors in the primitive streak. Development 129: 1107-1117.

KAEHN, K., JACOB, H.J., CHRIST, B., HINRICHSEN, K. and POELMANN, R.E. (1988) The onset of myotome formation in the chick. Anat.Embryol.(Berl). 177: 191-201.

KAWAKAMI, Y., RAYA, A., RAYA, R.M., RODRIGUEZ-ESTEBAN, C. and BELMONTE, J.C. (2005). Retinoic acid signalling links left-right asymmetric patterning and bilaterally symmetric somitogenesis in the zebrafish embryo. Nature 435: 165-171.

KEYNES, R.J. and STERN, C.D. (1984). Segmentation in the vertebrate nervous system. Nature 310: 786-789.

KEYNES, R.J. and STERN, C.D. (1988). Mechanisms of vertebrate segmentation Development. 103: 413-429.

KIENY, M., MAUGER, A. and SENGEL, P. (1972). Early regionalization of somitic mesoderm as studied by the development of axial skeleton of the chick embryo. Dev Biol. 28: 142-161.

KROL, A.J., ROELLIG, D., DEQUEANT, M.L., TASSY, O., GLYNN, E., HATTEM, G. MUSHEGIAN, A., OATES, A.C. and POURQUIE, O. (2011). Evolutionary plasticity of segmentation clock networks. Development 138: 2783-2792.

KRULL, C.E. (2001). Segmental organization of neural crest migration. Mech Dev 105: $37-45$.

LANCE-JONES, C. (1988). The somitic level of origin of embryonic chick hindlimb muscles. Dev Biol. 126: 394-407.

LE DOUARIN, N. (1969). [Details of the interphase nucleus in Japanese quail (Coturnix coturnix japonica)]. Bull Biol Fr Belg 103: 435-452

MARCELLE, C., STARK, M.R. and BRONNER-FRASER, M. (1997). Coordinate actions of BMPs, Wnts, Shh and Noggin mediate patterning of the dorsal somite. Development. 124: 3955-3963.

MAUGER, A. (1972). [Role of neural tube in the development of the dorsal plum- 
age in the chick embryo]. Wilhelm Roux Arch Entwickl Mech Org 170: 244-266. MCGREW, M.J., DALE, J.K., FRABOULET, S. and POURQUIE, O. (1998). The lunatic fringe gene is a target of the molecular clock linked to somite segmentation in avian embryos. Curr Biol 8: 979-982.

MCGREW, M.J., SHERMAN, A., LILLICO, S.G., ELLARD, F.M., RADCLIFFE, P.A., GILHOOLEY, H.J., MITROPHANOUS, K.A., CAMBRAY, N., WILSON, V. and SANG, H. (2008). Localised axial progenitor cell populations in the avian tail bud are not committed to a posterior Hox identity. Development 135: 2289-2299.

MEINHARDT, H. (1986). Models of segmentation. In Somites in Developing Embryos, (ed. R, B.DA, E. and JW, L.). Plenum press, New York and London, pp.179-191.

MENKES, B. and SANDOR, S. (1969). Researches on the development of axial organs. V. Rev Roum Embryol 6: 65-72.

MEYERS, E.N. and MARTIN, G.R. (1999). Differences in left-right axis pathways in mouse and chick: functions of FGF8 and SHH. Science 285: 403-406.

MORIMOTO, M., TAKAHASHI, Y., ENDO, M. and SAGA, Y. (2005). The Mesp2 transcription factor establishes segmental borders by suppressing Notch activity. Nature 435: 354-359.

NAKAYA, Y., KURODA, S., KATAGIRI, Y.T., KAIBUCHI, K. and TAKAHASHI, Y. (2004). Mesenchymal-Epithelial Transition during Somitic Segmentation Is Regulated by Differential Roles of Cdc42 and Rac1. Dev Cell 7: 425-438.

NEW, D.A. (1955). A new technique for the cultivation of the chick embryo in vitro. $J$ Embryol Exp Morphol 3: 326-331

NODEN, D.M. (1983). The embryonic origins of avian cephalic and cervical muscles and associated connective tissues. Am.J.Anat. 168: 257-276.

OGINUMA, M., NIWA, Y., CHAPMAN, D.L. and SAGA, Y. (2008). Mesp2 and Tbx6 cooperatively create periodic patterns coupled with the clock machinery during mouse somitogenesis. Development 135: 2555-2562.

OLIVERA-MARTINEZ, I., COLTEY, M., DHOUAILLY, D. and POURQUIE, O. (2000). Mediolateral somitic origin of ribs and dermis determined by quail-chick chimeras. Development 127: 4611-4617.

ORDAHL, C.P., BERDOUGO, E., VENTERS, S.J. and DENETCLAW, W.F., JR. (2001). The dermomyotome dorsomedial lip drives growth and morphogenesis of both the primary myotome and dermomyotome epithelium. Development 128: 1731-1744.

ORDAHL, C.P. and CHRIST, B. (1997). Avian somite transplantation: a review of basic methods. Methods Cell Biol. 52: 3-27.

ORDAHL, C.P. and LE DOUARIN, N.M. (1992). Two myogenic lineages within the developing somite. Development 114: 339-353.

PACKARD, D.S.J. and MEIER, S. (1983). An experimental study of the somitomeric organization of the avian segmental plate. Dev Biol. 97: 191-202.

PALMEIRIM, I., DUBRULLE, J., HENRIQUE, D., ISH-HOROWICZ, D. and POURQUIÉ, O. (1998). Uncoupling segmentation and somitogenesis in the chick presomitic mesoderm. Dev Genet. 23: 77-85.

PALMEIRIM, I., HENRIQUE, D., ISH-HOROWICZ, D. and POURQUIÉ, O. (1997). Avian hairy gene expression identifies a molecular clock linked to vertebrate segmentation and somitogenesis. Cell 91: 639-648.

POURQUIE, O., COLTEY, M., TEILLET, M.A., ORDAHL, C. and LE DOUARIN, N.M.
(1993). Control of dorsoventral patterning of somitic derivatives by notochord and floor plate. Proc Natl Acad Sci USA 90: 5242-5246.

RICKMANN, M., FAWCETT, J.W. and KEYNES, R.J. (1985). The migration of neural crest cells and the growth of motor axons through the rostral half of the chick somite. J.Embryol.Exp.Morphol. 90: 437-455.

SARRAZIN, A.F., PEEL, A.D. and AVEROF, M. (2012). A segmentation clock with two-segment periodicity in insects. Science 336: 338-341.

SATO, Y. and LANSFORD, R. (2013). Transgenesis and imaging in birds, and available transgenic reporter lines. Dev Growth Differ 55: 406-421.

SATO, Y., YASUDA, K. and TAKAHASHI, Y. (2002). Morphogical boundary forms by a novel inductive enevt mediated by Lunatic fringe and Notch during somitic segmentation. Development 129: 3633 - 3644.

SCHRAGLE, J., HUANG, R., CHRIST, B. and PROLS, F. (2004). Control of the temporal and spatial Uncx4.1 expression in the paraxial mesoderm of avian embryos. Anat Embryol (Berl) 208: 323-332.

SELLECK, M.A. and STERN, C.D. (1991). Fate mapping and cell lineage analysis of Hensen's node in the chick embryo. Development. 112: 615-626.

SHEARMAN, R.M., TULENKO, F.J. and BURKE, A.C. (2011). 3D reconstructions of quail-chick chimeras provide a new fate map of the avian scapula. Dev Biol355:1-11.

STERN, C.D. and KEYNES, R.J. (1987). Interactions between somite cells: the formation and maintenance of segment boundaries in the chick embryo. Development. 99: 261-272.

STERN, H.M. and HAUSCHKA, S.D. (1995). Neural tube and notochord promote in vitro myogenesis in single somite explants. Dev Biol. 167: 87-103.

STRUDEL, G. (1955). L'action morphogène du tube nerveux et de la corde sur la différenciation des Vertébrés et des muscles vertébraux chez l'embryon de Poulet. Arch.Anat.Microsc.Morph.Exp. 44: 209-235.

TANAKA, M. and TICKLE, C. (2004). Tbx18 and boundary formation in chick somite and wing development. Dev Biol 268: 470-80.

VERMOT, J., LLAMAS, J.G., FRAULOB, V., NIEDERREITHER, K., CHAMBON, P. and DOLLE, P. (2005). Retinoic acid controls the bilateral symmetry of somite formation in the mouse embryo. Science 308: 563-566.

VERMOT, J. and POURQUIE, O. (2005). Retinoic acid coordinates somitogenesis and left-right patterning in vertebrate embryos. Nature 435: 215-220.

VILHAIS-NETO, G.C., MARUHASHI, M., SMITH, K.T., VASSEUR-COGNET, M., PETERSON, A.S., WORKMAN, J.L. and POURQUIE, O. (2010). Rere controls retinoic acid signalling and somite bilateral symmetry. Nature 463: 953-957.

VON EBNER, V. (1888). Urwirbel und Neugliederung der WirbelSäule. Sitzungsber. Akad.Wiss. Wien III/97: 194-206.

WATANABE, T., SATO, Y., SAITO, D., TADOKORO, R. and TAKAHASHI, Y. (2009) EphrinB2 coordinates the formation of a morphological boundary and cell epithelialization during somite segmentation. Proc Natl Acad Sci USA 106: 7467-7472.

WELLIK, D.M. (2007). Hox patterning of the vertebrate axial skeleton. Dev Dyn 236 2454-2463.

YASUGI, S. and NAKAMURA, H. (2000). Gene transfer into chicken embryos as an effective system of analysis in developmental biology. Dev Growth Differ42: 195-197. 


\section{Further Related Reading, published previously in the Int. J. Dev. Biol.}

SDF-1 controls the muscle and blood vessel formation of the somite

Aisha Abduelmula Ruijin HuangQin Pu, Hirokazu Tamamura, Gabriela Morosan-Puopolo and Beate Brand-Saberi

Int. J. Dev. Biol. (2016) 60: 29-38

https://doi.org/10.1387/ijdb.150132rh

Neuronal induction and regional identity by co-culture of adherent human embryonic stem cells with chicken notochords and somites Hossein Salehi, Khadijeh Karbalaie, Shahnaz Razavi, Somaieh Tanhaee, Marziyh Nematollahi, Mohsen Sagha, Mohammad-Hossein Nasr-Esfahani and Hossein Baharvand Int. J. Dev. Biol. (2011) 55: 321-326

https://doi.org/10.1387/ijdb.103185hs

Portuguese contributions to the discovery and characterization of the embryonic molecular clock

Susana Pascoal and Isabel Palmeirim

Int. J. Dev. Biol. (2009) 53: 1421-1426

https://doi.org/10.1387/ijdb.072285sp

A comparative analysis of Meox1 and Meox2 in the developing somites and limbs of the chick embryo

Susan Reijntjes, Sigmar Stricker and Baljinder S. Mankoo

Int. J. Dev. Biol. (2007) 51: 753-759

https://doi.org/10.1387/ijdb.072332sr

Mouse-chick neural chimeras

Josiane Fontaine-Pérus and Yvonnick Chéraud

Int. J. Dev. Biol. (2005) 49: 349-353

http://www.intjdevbiol.com/web/paper/041943jf

5 yr ISI Impact Factor $(2016)=2.421$
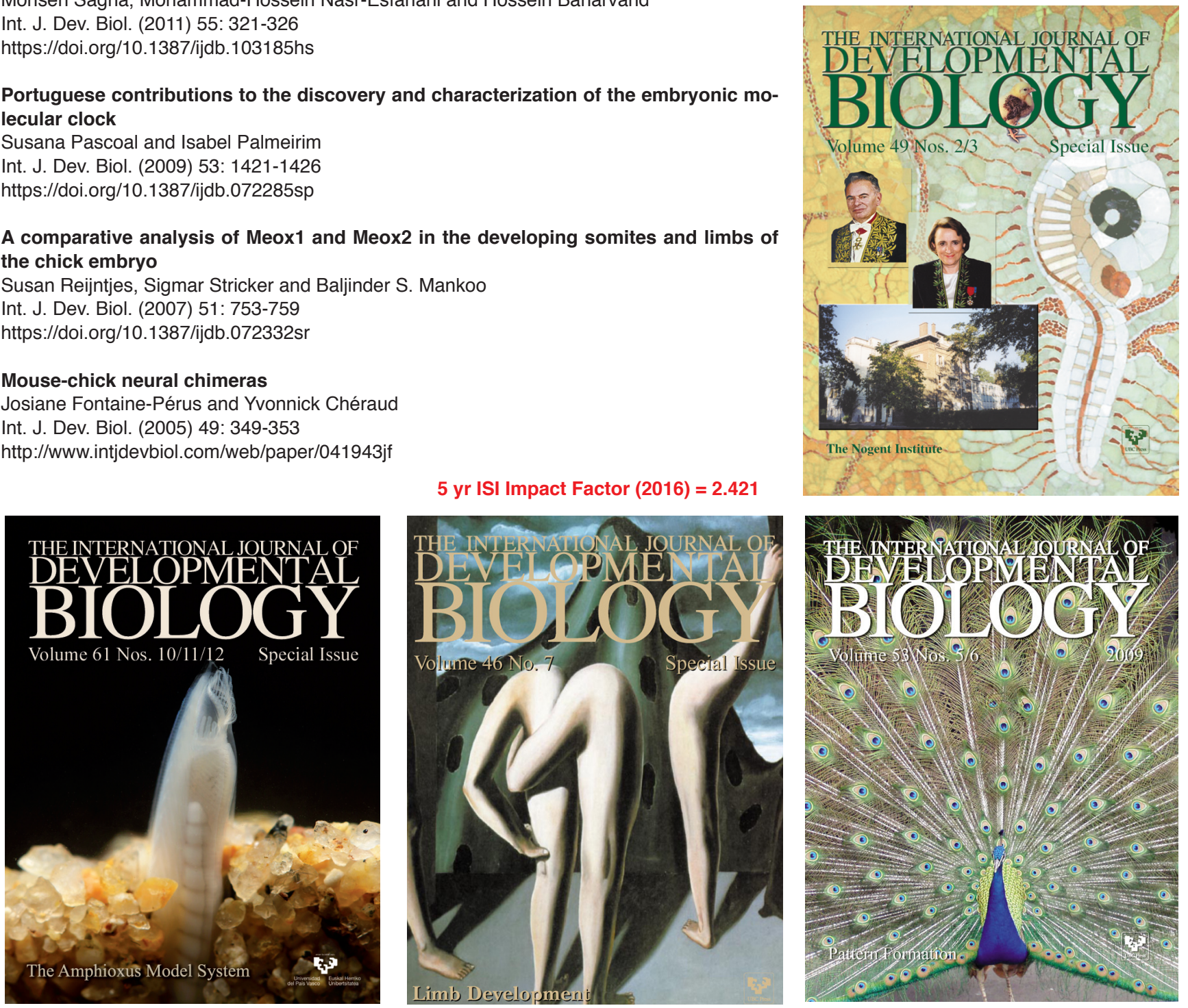